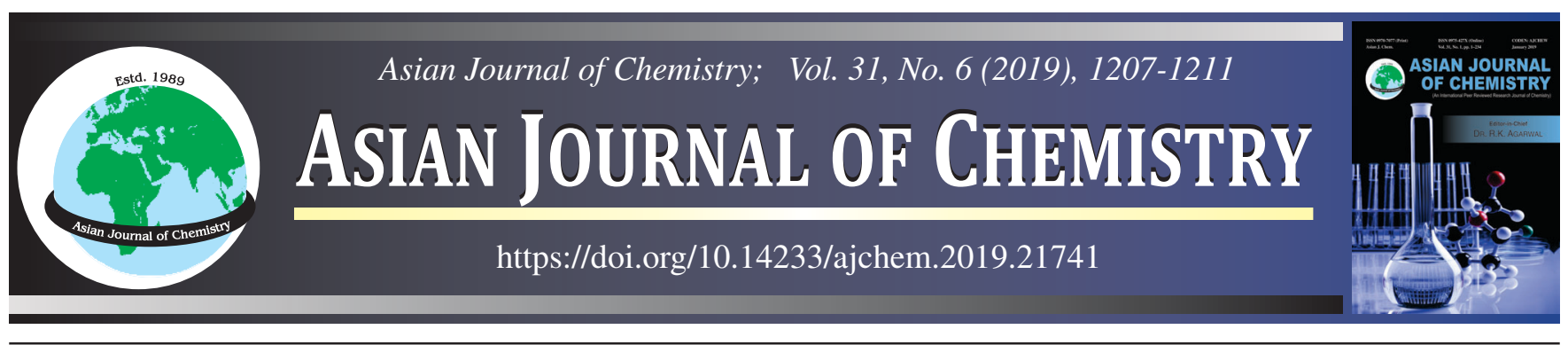

\title{
Study of Antimicrobial Activity of Actinomycetes Isolates from Non-Medicinal Plants Produced Soil \& Soil Surrounding Medicinal Plants in Junagadh, India
}

\author{
RAm DARShit $^{1,{ }^{*}}$ and DeVAng PANDYA ${ }^{2}$
}

${ }^{1}$ Noble Pharmacy College, Noble Group of Institutions, Bhesan Road, Bamangam, Junagadh-362310, India

${ }^{2}$ School of Pharmacy, R K University, Rajkot-360020, India

*Corresponding author: E-mail: dramahir@gmail.com

Received: 5 October 2018;

Accepted: 1 December 2018;

Published online: 29 April 2019;

AJC-19356

Isolation and screening of actinomycetes and compare its antimicrobial activity from non-medicinal plant produced soil with soil surrounding medicinal plant. In this study total 22 soil samples collected in two sets one from soil surrounding medicinal plant area of Junagadh and other not nearby medicinal plant of same region. Primary screening of isolate done using cross streak method with 8 test pathogens. Secondary screening of most potent 10 isolates equal from both sets by agar well diffusion. Thirty two isolate observed from soil samples of 11 places which were not nearby medicinal plants and 36 isolate observed from soil samples collected surrounding 11 different medicinal plants. (A)OS1, (A)OS3, (A)AI1, (A)TF1 and (A)RI1 were most potent isolates produced from soil surrounding medicinal plant compare to set 2 . It was found set 1 showed $72.22 \%$ and set 2 showed $53.12 \%$ activity.

Keywords: Actinomycets, Potent, Antimicrobial, Isolate, Medicinal.

\section{INTRODUCTION}

Soil is most outer layer of surface of earth and its characteristics are different in its layer like most outer layer is loose soil while in deeper layer is hard rock also so many other layers are present in it. For agriculture point of view soil plays important role for development of plants on the surface of earth. In soil there are many biological interactions take places and those are the interest in particularly microbiological aspects. Soil is rich source of diverse microbes. Locality and climate is main factor affecting on microorganism amount and proposition of microorganisms. One of the main functions like decomposition of many organic materials is possible because of the microorganisms. Soil microbiology plays important role in study of microorganisms and their activities [1].

Amongst all the living species on the earth microorganisms is most old in them on our planet. The dependence is in relative manner like we depends on plants for our nutrition. Plants depends on soil for their nutrition and microorganisms are responsible for make soil capable for developing plants. Many researchers studied those microorganisms from various sources like air, water and soil. After that they came to know that the importance of those microbes in cycle of earth's existence. Before, we came able to know this microorganism exists with their all functions [2]. Also microorganisms decompose the organic material like dead body of species by many biochemical reactions on them so in soil and also many variety of those microorganisms' are present in soil. Ultimately soil is very rich source of diverse microbes.

Mainly soil is composed of organic, mineral, air in soil, water in soil and microorganisms in soil. Locality and climate are main factors affecting on microorganism amount and proposition of microorganisms. Soil is like one living system for different species of microbes. In respect to proportion bacteria is more in numbers while compare with other groups. Because of size of microorganisms they occupy very less space on soil and few percentage. In soil each and every microbes and there group have their specific role like it affects the growth and development of various plants also make soil fertile. Some constitute from animals and plants play as one of components in soil structure. So, soil is one type of medium for all that natures' activities [3].

Soil is cultivated has more rich numbers of microorganisms and other living organisms. Fertility of soil depends on

This is an open access journal, and articles are distributed under the terms of the Creative Commons Attribution-NonCommercial-ShareAlike 4.0 (CC BY-NC-SA 4.0) International License which allows readers to freely read, download, copy, distribute, print, search, or link to the full texts of its articles and to use them for any other lawful non-commercial purpose as long as the original source is duly acknowledged. 
microbes, which are present in soil and productivity of soil is depending on them. In respect to nutritional sources of environment for maintaining nature's cycle is affected by presence of microorganisms. Some microorganisms are responsible for many human diseases as well as plant and other species diseases. So, both the type of effect is there of microorganism positive and negative.

There are wide application and scope of soil microbiology like pharmaceutical, industrial, medicinal, beverages and sprit production, used in fermented food industries, production of insecticides pesticides, production of amino acids, manufacture of antibiotics, manufacture of therapeutic enzymes, steroids production, single cell protein production, geochemical field, aero microbiology, waste treatment area, agriculture sector, etc. Streptomyces is most important amongst all genuses of actinomycetes and the genera that are in non-streptomyces group are very rare approximately hundred genera [4-8].

\section{EXPERIMENTAL}

All cultural media, chemicals, reagents, diagnostic kit used are from Himedia laboratories, Mumbai, India.

In present study, we selected random places in Girnar forest area of Saurashtra, Gujarat state, India. Soil samples collected in two sets one was soil surrounding Aloe vera, Azadirachta indica, Syzygium cumini, Datura stramonium, Rosa indica, Pongamia pinnata, Oscimum sanctum, Allium sativum, Allium cepa, Trigonella foenum-graecum, Psoralea corylifolia and another set was non-medicinal plant area soil. Micro flora part of soil is used because maximum numbers of microbes were present in this part of soil. $3 \mathrm{~cm}$ surface soil separated and up to $25 \mathrm{~cm}$ depth part of soil is used for sample collection. Sterile tube used for collection and storage of samples. Stainless steel sterile spatula and scoops used in collection process.

Sample treatment: During collection, transportation and storage of soil samples, care has been taken to minimize contamination. Air tight sterile tubes were used for storage. In laminar air flow (LAF) soil samples were dried at room temperature and stored at $4{ }^{\circ} \mathrm{C}$ until use. All the glassware and other apparatus were sterilized by autoclave and used in dilution of soil samples. Samples were diluted up to $10^{-6}$ by serial dilution method. First step take $1 \mathrm{~g}$ of soil and $99 \mathrm{~mL}$ water in conical flask. Vortex sample and serially make further dilutions. Prepared samples $0.1 \mathrm{~mL}$ in quantity from last diluted step, which was used for further process.

Prepared starch casein agar media and steriled by autoclave then added Nystatin $(50 \mu \mathrm{g} / \mathrm{mL})$ in petri-dishes under laminar air flow. Soil samples were added in $0.1 \mathrm{~mL}$ quantity and spread on the surface of media with help of sterile glass rod bent in structure. Then left at $28^{\circ} \mathrm{C}$ for 1 week and observe growth of microbes on plates. By using streak plate method make pure colonies of actinomycetes using same media which colonies developed.

\section{Characteristics of actinomycetes isolates}

Colony characteristics: Based on appearance and morphological characters colonies of actinomycets were selected and mycelium colour and physical structure were observed. Different types of appearance of colonies like smooth, lathery, dry etc. were studied and interpreted results of both set of samples [9].
Total 46 actinomycetes isolates were found by using 22 soil samples (11 soil samples from surrounding soil of medicinal plant area and 11 soil samples from not nearby medicinal plant area).

Microscopic examination: Cover slip cultures of isolates were prepared by using ISP agar media. Sterile cover slip used and inserted at $45^{\circ}$ angle on the surface of media and after incubation plates were studied in respect to growth of colonies. Incubation duration was 7 days at $28{ }^{\circ} \mathrm{C}$ temperature. Study growth of microbes in cover slip by microscopic examination in respect to mycelium growth, sporulation and all morphological parameters [10].

Primary screening for antimicrobial activity: Based on colony characteristics all isolates were used for screening for antimicrobial activity. Cross streak method used for microbe's growth. There are different methods available for screening purpose but because of easy operation with fast results cross streak is widely used amongst other. Muller Hinton agar (MHA) media was prepared. Ingredients like meat, casein acid hydrolyzate, starch and agar used in composition of MHA media with $\mathrm{pH} 7.3 \pm 0.1$ at $25^{\circ} \mathrm{C}$. Autoclave used for sterilization of media at $121{ }^{\circ} \mathrm{C}$ for $30 \mathrm{~min}$. After some time media solidify at room temperature, which were used for further inoculation process with actinomycetes cultures with single line streak in petri dishes centre after that incubated at $20^{\circ} \mathrm{C}$ for 7 days. This allow well diffuse of microbes in media and good growth of them [11].

After observing a good growth on the petri plates, the test organisms were streaked at right angles to the streak of actinomycets without touching central growth of actinomycets and plates were incubated at $30^{\circ} \mathrm{C}$ for $24 \mathrm{~h}$. After incubation length of streak growth was measured. Different 8 pathogenic microbes used to check antimicrobial activity of isolates. Measure the inhibition area [12].

Secondary screening: Top 5 isolates were selected for secondary screening based on their antimicrobial activity. Prepared sterile MHA media and allow solidifying at room temperature. Inoculate different pathogens on plate and allow incubating at $20^{\circ} \mathrm{C}$ for 7 days [13].

Make bore or well around $8 \mathrm{~mm}$ diameter in solid media with help of sterile stainless steel borer procedure done under aseptic chamber. Add $0.1 \mathrm{~mL}$ of isolate extract from selected isolates and kept for $37{ }^{\circ} \mathrm{C}$ for 7 to 9 days. Extract prepared from using $2.5 \%$ microbial broth and centrifugation at 5000 rpm for $1 \mathrm{~h}$. After duration of incubation observed growth of microbes and zone of inhibition surrounding well [14]. Disk diffusion method also used to check antimicrobial activity of selected actinomycete isolates. In this method disk were prepared using 1:1 volume of extracted isolate broth of samples. Zone of inhibition was measured surrounding disk of samples.

\section{RESULTS AND DISCUSSION}

Morphological characterization: Based on colony morphology 32 actinomycetes isolate observed from soil samples of 11 places which were not nearby medicinal plants and 36 actinomycetes isolate observed from soil samples collected surrounding 11 different medicinal plants. 
Actinomycete isolates produced from soil nearby 11 different medicinal plants area showed arial mycelium white colour of colony in $20(55.56 \%)$ isolates, cream colour of colony in $5(13.89 \%)$ isolates, yellow colour of colony in 4 $(11.11 \%)$ of isolates, brown colour of colony in $3(8.33 \%)$ of isolates, gray colour of colony in $2(5.56 \%)$ isolates, pinkish colour of colony in $1(2.78 \%)$ of isolate and bluish colour of colony in $1(2.78 \%)$ of isolates.

Actinomycete isolates produced from soil nearby 11 different medicinal plants area showed vegitative mycelium yellow colour of colony in $16(44.44 \%)$ isolates, white colour of colony in $7(19.44 \%)$ isolates, cream colour of colony in 5 $(13.89 \%)$ of isolates, brown colour of colony in $4(11.11 \%)$ of isolates, gray colour of colony in $3(8.33 \%)$ isolates and redish colour of colony in $1(2.78 \%)$ of isolates.

Soil is rich source of different types of microorganism produced antimicrobial activity against many harmful pathogens $[15,16]$. Some study also shown that white colour of arial mycelium was dominant and yellow colour is in the case of vegetative mycelium colony [17]. Also more diversity of colony colour was observed in arial mycelium than vegetative mycelium colony [18]. Previous study shown that diversity to produce potent actinomycetes was depend on ecological regions [19].

Actinomycete isolates produced from soil not nearby medicinal plants area showed arial mycelium white colour of colony in $17(53.13 \%)$ isolates, cream colour of colony in 5 $(15.63 \%)$ isolates, yellow colour of colony in $4(12.50 \%)$ of isolates, brown colour of colony in $2(6.25 \%)$ of isolates, gray colour of colony in $2(6.25 \%)$ isolates, pinkish colour of colony in $1(3.13 \%)$ of isolate and bluish colour of colony in $1(3.13 \%)$ of isolates.

Actinomycete isolates produced from soil not nearby medicinal plants area showed vegitative mycelium yellow colour of colony in $15(46.88 \%)$ isolates, white colour of colony in $6(18.75 \%)$ isolates, cream colour of colony in 4 $(12.50 \%)$ of isolates, brown colour of colony in $4(12.50 \%)$ of isolates, gray colour of colony in $2(6.25 \%)$ isolates and redish colour of colony in $1(3.13 \%)$ of isolates.

Screening for antimicrobial activity: It was found that 36 actinomycetes isolates observed from soil surrounding medicinal plant area and all isolated used for primary screening against 8 test pathogens. It was found that against Bacillus subtilis 12 isolates not showed any activity, 5 isolates showed more than $20 \mathrm{~mm} \mathrm{ZOI,} 11$ isolates showed 15 to $20 \mathrm{~mm} \mathrm{ZOI,}$ 3 isolates showed 10 to $15 \mathrm{~mm} \mathrm{ZOI} \mathrm{and} 5$ isolates showed less than $10 \mathrm{~mm}$ ZOI. Against Staphylococcus aureus 16 isolates showed not any activity, 6 isolates showed more than $20 \mathrm{~mm}$ ZOI, 9 isolates showed 15 to $20 \mathrm{~mm}$ ZOI, 2 isolates showed 10 to $15 \mathrm{~mm}$ ZOI and 3 isolates showed less than $10 \mathrm{~mm}$ ZOI. Against Proteus vulgaris 19 isolates showed not any activity, 3 isolates showed more than $20 \mathrm{~mm}$ ZOI, 5 isolates showed 15 to $20 \mathrm{~mm}$ ZOI, 3 isolates showed 10 to $15 \mathrm{~mm}$ ZOI and 6 isolates showed less than $10 \mathrm{~mm}$ ZOI. Against Escherichia coli 13 isolates showed not any activity, 3 isolates showed

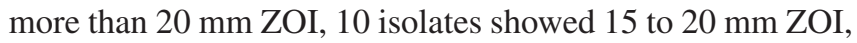
1 isolates showed 10 to $15 \mathrm{~mm} \mathrm{ZOI} \mathrm{and} 9$ isolates showed less than $10 \mathrm{~mm}$ ZOI.

Against Klebsiella aerogenes 14 isolates showed not any activity, 4 isolates showed more than $20 \mathrm{~mm}$ ZOI, 10 isolates showed 15 to $20 \mathrm{~mm} \mathrm{ZOI,} 2$ isolates showed 10 to $15 \mathrm{~mm} \mathrm{ZOI}$ and 6 isolates showed less than $10 \mathrm{~mm}$ ZOI. Against Pseudomonas aeruginosa 21 isolates showed not any activity, 3 isolates showed more than $20 \mathrm{~mm}$ ZOI, 5 isolates showed 15 to $20 \mathrm{~mm} \mathrm{ZOI,} 1$ isolates showed 10 to $15 \mathrm{~mm} \mathrm{ZOI} \mathrm{and} 6$ isolates showed less than $10 \mathrm{~mm}$ ZOI. Against Salmonella typhi 24 isolates showed not any activity, 0 isolates showed more than $20 \mathrm{~mm}$ ZOI, 5 isolates showed 15 to $20 \mathrm{~mm}$ ZOI, 1 isolates showed 10 to $15 \mathrm{~mm} \mathrm{ZOI} \mathrm{and} 6$ isolates showed less than $10 \mathrm{~mm}$ ZOI. Against Enterobacter aerogenes 22 isolates showed not any activity, 0 isolates showed more than $20 \mathrm{~mm}$ ZOI, 4 isolates showed 15 to $20 \mathrm{~mm}$ ZOI, 2 isolates showed 10 to $15 \mathrm{~mm} \mathrm{ZOI} \mathrm{and} 8$ isolates showed less than $10 \mathrm{~mm}$ ZOI (Table-1).

It was found that 36 actinomycetes isolates observed from soil not surrounding medicinal plant area and all isolated used for primary screening against 8 test pathogens. It was found that against Bacillus subtilis, 11 isolates not showed any activity, 4 isolates showed more than $20 \mathrm{~mm} \mathrm{ZOI,} 10$ isolates showed 15 to $20 \mathrm{~mm} Z O I, 2$ isolates showed 10 to $15 \mathrm{~mm}$ ZOI and 5 isolates showed less than $10 \mathrm{~mm}$ ZOI. Against Staphylococcus aureus 14 isolates showed not any activity, 5 isolates showed more than $20 \mathrm{~mm}$ ZOI, 8 isolates showed 15 to $20 \mathrm{~mm}$ ZOI, 2 isolates showed 10 to $15 \mathrm{~mm}$ ZOI and 3 isolates showed less than $10 \mathrm{~mm}$ ZOI. Against Proteus vulgaris 17 isolates showed not any activity, 3 isolates showed more than $20 \mathrm{~mm} \mathrm{ZOI,} 4$ isolates showed 15 to $20 \mathrm{~mm} \mathrm{ZOI,} 3$ isolates showed 10 to $15 \mathrm{~mm} \mathrm{ZOI}$ and 5 isolates showed less than 10 $\mathrm{mm}$ ZOI. Against Escherichia coli 11 isolates showed not any activity, 3 isolates showed more than $20 \mathrm{~mm}$ ZOI, 8 isolates showed 15 to $20 \mathrm{~mm}$ ZOI, 1 isolates showed 10 to $15 \mathrm{~mm}$ ZOI and 9 isolates showed less than $10 \mathrm{~mm}$ ZOI (Table-2).

TABLE-1

DISTRIBUTION OF ACTINOMYCETES ISOLATES PRODUCED FROM SOIL SURROUNDING MEDICINAL PLANTS SHOWED ANTIMICROBIAL ACTIVITY AGAINST TEST PATHOGENS

\begin{tabular}{|c|c|c|c|c|c|c|}
\hline Test pathogens & Not active & $>20 \mathrm{~mm}$ & $15-20 \mathrm{~mm}$ & $10-15 \mathrm{~mm}$ & $<10 \mathrm{~mm}$ & $\begin{array}{l}\text { Total number of } \\
\text { isolates }\end{array}$ \\
\hline Bacillus subtilis & 12 & 5 & 11 & 3 & 5 & 36 \\
\hline Staphylococcus aureus & 16 & 6 & 9 & 2 & 3 & 36 \\
\hline Proteus vulgaris & 19 & 3 & 5 & 3 & 6 & 36 \\
\hline Escherichia coli & 13 & 3 & 10 & 1 & 9 & 36 \\
\hline Klebsiella aerogenes & 14 & 4 & 10 & 2 & 6 & 36 \\
\hline Pseudomonas aeruginosa & 21 & 3 & 5 & 1 & 6 & 36 \\
\hline Salmonella typhi & 24 & 0 & 5 & 1 & 6 & 36 \\
\hline Enterobacter aerogenes & 22 & 0 & 4 & 2 & 8 & 36 \\
\hline
\end{tabular}




\begin{tabular}{|c|c|c|c|c|c|c|}
\hline \multicolumn{7}{|c|}{$\begin{array}{c}\text { TABLE-2 } \\
\text { DISTRIBUTION OF ACTINOMYCETES ISOLATES PRODUCED FROM SOIL NOT SURROUNDING } \\
\text { MEDICINAL PLANTS SHOWED ANTIMICROBIAL ACTIVITY AGAINST TEST PATHOGENS }\end{array}$} \\
\hline Test pathogens & Not active & $>20 \mathrm{~mm}$ & $15-20 \mathrm{~mm}$ & $10-15 \mathrm{~mm}$ & $<10 \mathrm{~mm}$ & $\begin{array}{l}\text { Total number of } \\
\text { isolates }\end{array}$ \\
\hline Bacillus subtilis & 11 & 4 & 10 & 2 & 5 & 32 \\
\hline Staphylococcus aureus & 14 & 5 & 8 & 2 & 3 & 32 \\
\hline Proteus vulgaris & 17 & 3 & 4 & 3 & 5 & 32 \\
\hline Escherichia coli & 11 & 3 & 8 & 1 & 9 & 32 \\
\hline Klebsiella aerogenes & 12 & 4 & 9 & 2 & 5 & 32 \\
\hline Pseudomonas aeruginosa & 19 & 3 & 4 & 1 & 5 & 32 \\
\hline Salmonella typhi & 22 & 0 & 4 & 1 & 5 & 32 \\
\hline Enterobacter aerogenes & 20 & 0 & 3 & 2 & 7 & 32 \\
\hline
\end{tabular}

Against Klebsiella aerogenes 12 isolates showed not any activity, 4 isolates showed more than $20 \mathrm{~mm}$ ZOI, 9 isolates showed 15 to $20 \mathrm{~mm} \mathrm{ZOI,} 2$ isolates showed 10 to $15 \mathrm{~mm} \mathrm{ZOI}$ and 5 isolates showed less than $10 \mathrm{~mm}$ ZOI. Against Pseudomonas aeruginosa 19 isolates showed not any activity, 3 isolates showed more than $20 \mathrm{~mm} \mathrm{ZOI,} 4$ isolates showed 15 to $20 \mathrm{~mm}$ ZOI, 1 isolates showed 10 to $15 \mathrm{~mm} \mathrm{ZOI} \mathrm{and} 5$ isolates showed less than $10 \mathrm{~mm}$ ZOI. Against Salmonella typhi 22 isolates showed not any activity, 0 isolates showed more than $20 \mathrm{~mm} \mathrm{ZOI,} 4$ isolates showed 15 to $20 \mathrm{~mm} \mathrm{ZOI,} 1$ isolates showed 10 to $15 \mathrm{~mm} Z O I$ and 5 isolates showed less than 10 $\mathrm{mm}$ ZOI. Against Enterobacter aerogenes 20 isolates showed not any activity, 0 isolates showed more than $20 \mathrm{~mm}$ ZOI, 3 isolates showed 15 to $20 \mathrm{~mm} \mathrm{ZOI,} 2$ isolates showed 10 to 15 $\mathrm{mm} \mathrm{ZOI} \mathrm{and} 7$ isolates showed less than $10 \mathrm{~mm} \mathrm{ZOI} \mathrm{(Table-2).}$

Study shown that chances to produced atinomycetes isolates from agriculture soil was greater than non-agriculture soil isolates [20].

Some study states that there were marginal difference of actinomycetes isolates shown more than $15 \mathrm{~mm}$ ZOI from firtile and non firtile soil isolates [21-23]. Here we found that there were around 20 to $30 \%$ more chances to show activity more than $15 \mathrm{~mm}$ of isolate produced from soil collected nearby medicinal plant area versus actinomycetes isolate produceed from soil not nearby medicinal plant area.

Top 5 actinomycetes isolates selected from both sets for further process. Agar well diffusion method was used for secondary screening of most potent actinomycetes isolates.
The isolates (A)OS3 showed $20 \mathrm{~mm}$ ZOI against Bacillus subtilis, (B)TF2 showed $18 \mathrm{~mm}$ ZOI against Bacillus subtilis, (A)OS3 shows $21 \mathrm{~mm}$ ZOI against Escherichia coli, (B)RI1 showed $18 \mathrm{~mm}$ ZOI against Escherichia coli (Table-3).

Only five actinomycetes isolate shown antimicrobial activity against pathogens out 70 isolates produced from soil of Madhya Pradesh, India [2,12]. No actinomycetes isolated shown more than $20 \mathrm{~mm}$ ZOI against test pathogens used for antimicrobial activity out of 43 isolates of Saudi University garden area [6,24-26].

It was observed that iaolate (A)OS1 showed $27.00 \pm 1$ ZOI against Bacillus subtilis, $22.00 \pm 1$ ZOI against Staphylococcus aureus, $24.67 \pm 0.58 \mathrm{ZOI}$ against Proteus vulgaris, $20.00 \pm 1 \mathrm{ZOI}$ against Escherichia coli, $26.00 \pm 1 \mathrm{ZOI}$ against Klebsiella aerogenes, $19.00 \pm 1 \mathrm{ZOI}$ against Salmonella typhi and $18.33 \pm 0.58 \mathrm{ZOI}$ against Enterobacter aerogenes. Isolate (A)OS3 showed 20.00 \pm 1 ZOI against Bacillus subtilis, 20.33 $\pm 0.58 \mathrm{ZOI}$ against Staphylococcus aureus, $21.33 \pm 0.58 \mathrm{ZOI}$ against Proteus vulgaris, $21.00 \pm 1 \mathrm{ZOI}$ against Escherichia coli, $18.67 \pm 0.58 \mathrm{ZOI}$ against Klebsiella aerogenes, $19.00 \pm$ $1 \mathrm{ZOI}$ against Salmonella typhi and $16.00 \pm 1 \mathrm{ZOI}$ against Enterobacter aerogenes. Isolate (A)AI1 showed $25.00 \pm 1 \mathrm{ZOI}$ against Bacillus subtilis, $19.33 \pm 0.58 \mathrm{ZOI}$ against Staphylococcus aureus, $18.67 \pm 0.58 \mathrm{ZOI}$ against Proteus vulgaris, $18.33 \pm 0.58$ ZOI against Escherichia coli, $20.00 \pm 1$ ZOI against Klebsiella aerogenes, $20.00 \pm 1$ ZOI against Salmonella typhi and $21.00 \pm 1 \mathrm{ZOI}$ against Enterobacter aerogenes. Isolate (A)TF1 showed 18.67 $\pm 0.58 \mathrm{ZOI}$ against Bacillus subtilis, 20.33

TABLE-3

ZONE OF INHIBITION (ZOI) AGAINST TEST PATHOGENS OF BOTH SETS OF TOP 5 POTENT ISOLATES

\begin{tabular}{|c|c|c|c|c|c|c|c|c|}
\hline \multirow{2}{*}{$\begin{array}{l}\text { Isolates code } \\
\text { name }\end{array}$} & \multicolumn{8}{|c|}{ Microbial species } \\
\hline & $\begin{array}{c}\text { Bacillus } \\
\text { subtilis }\end{array}$ & $\begin{array}{c}\text { Staphylococcus } \\
\text { aureus }\end{array}$ & $\begin{array}{l}\text { Proteus } \\
\text { vulgaris }\end{array}$ & $\begin{array}{c}\text { Escherichia } \\
\text { coli }\end{array}$ & $\begin{array}{l}\text { Klebsiella } \\
\text { aerogenes }\end{array}$ & $\begin{array}{c}\text { Pseudomonas } \\
\text { aeruginosa }\end{array}$ & $\begin{array}{c}\text { Salmonella } \\
\text { typhi }\end{array}$ & $\begin{array}{c}\text { Enterobacter } \\
\text { aerogenes }\end{array}$ \\
\hline \multicolumn{9}{|c|}{ Isolates produced from soil surrounding medicinal plant area } \\
\hline (A)OS1 & $27.00 \pm 1$ & $22.00 \pm 1$ & $24.67 \pm 0.58$ & $20.00 \pm 1$ & $26.00 \pm 1$ & 0 & $19.00 \pm 1$ & $18.33 \pm 0.58$ \\
\hline (A)OS3 & $20.00 \pm 1$ & $20.33 \pm 0.58$ & $21.33 \pm 0.58$ & $21.00 \pm 1$ & $18.67 \pm 0.58$ & 0 & $19.00 \pm 1$ & $16.00 \pm 1$ \\
\hline (A)AI1 & $25.00 \pm 1$ & $19.33 \pm 0.58$ & $18.67 \pm 0.58$ & $18.33 \pm 0.58$ & $20.00 \pm 1$ & 0 & $20.00 \pm 1$ & $21.00 \pm 1$ \\
\hline (A)TF1 & $18.67 \pm 0.58$ & $20.33 \pm 1.15$ & $22.00 \pm 2$ & $20.00 \pm 1$ & $20.67 \pm 0.58$ & $22.33 \pm 1.15$ & 0 & 0 \\
\hline (A)RI1 & $20.67 \pm 0.58$ & $22.67 \pm 0.58$ & $23.00 \pm 1$ & $20.67 \pm 1.15$ & $21.33 \pm 0.58$ & $20.00 \pm 1$ & 0 & 0 \\
\hline \multicolumn{9}{|c|}{ Isolates produced from soil not surrounding medicinal plant area } \\
\hline (B)3 & $19.67 \pm 0.58$ & $22.67 \pm 1.53$ & 0 & $20.00 \pm 01$ & $18.33 \pm 0.58$ & $19.67 \pm 0.58$ & 0 & 0 \\
\hline (B) 7 & $19.33 \pm 0.58$ & $20.00 \pm 1$ & 0 & $18.00 \pm 1$ & $20.00 \pm 1$ & $19.67 \pm 0.58$ & 0 & $16.67 \pm 0.58$ \\
\hline (B) 8 & $21.67 \pm 0.58$ & $17.33 \pm 0.58$ & 0 & $20.00 \pm 1$ & $20.00 \pm 1$ & $18.67 \pm 0.58$ & 0.00 & $15.33 \pm 0.58$ \\
\hline (B) 16 & $21.00 \pm 1$ & $21.67 \pm 0.58$ & 0 & $20.00 \pm 1$ & $19.33 \pm 0.58$ & $17.00 \pm 1$ & 0 & $18.33 \pm 0.58$ \\
\hline (B) 30 & $18.67 \pm 0.58$ & $19.33 \pm 0.58$ & $21.00 \pm 1$ & $22.00 \pm 1$ & $20.67 \pm 0.58$ & $19.33 \pm 0.58$ & 0 & 0 \\
\hline
\end{tabular}

Values are mean \pm SD of three replications. 
$\pm 1.15 \mathrm{ZOI}$ against Staphylococcus aureus, $22.00 \pm 2 \mathrm{ZOI}$ against Proteus vulgaris, $20.00 \pm 1 \mathrm{ZOI}$ against Esche-richia coli, 20.67 $\pm 0.58 \mathrm{ZOI}$ against Klebsiella aerogenes and $22.33 \pm 1.15 \mathrm{ZOI}$ against Pseudomonas aeruginosa. Isolate (A)RI1 showed 20.67 $\pm 0.58 \mathrm{ZOI}$ against Bacillus subtilis, $22.67 \pm 0.58 \mathrm{ZOI}$ against Staphylococcus aureus, $23.00 \pm 1 \mathrm{ZOI}$ against Proteus vulgaris, $20.67 \pm 1.15$ ZOI against Escherichia coli, $21.33 \pm 0.58 \mathrm{ZOI}$ against Klebsiella aerogenes and $20.00 \pm 1 \mathrm{ZOI}$ against Pseudomonas aeruginosa.

It was observed that isolate (B) 1 showed $19.67 \pm 0.58 \mathrm{ZOI}$ against Bacillus subtilis, $22.67 \pm 1.53$ ZOI against Staphylococcus aureus, $20.00 \pm 01 \mathrm{ZOI}$ against Escherichia coli, $18.33 \pm 0.58$ ZOI against Klebsiella aerogenes and $19.67 \pm 0.58 \mathrm{ZOI}$ against Pseudomonas aeruginosa. Isolate (B)2 showed $19.33 \pm 0.58 \mathrm{ZOI}$ against Bacillus subtilis, $20.00 \pm 1 \mathrm{ZOI}$ against Staphylococcus aureus, $18.00 \pm 1 \mathrm{ZOI}$ against Escherichia coli, $20.00 \pm 1 \mathrm{ZOI}$ against Klebsiella aerogenes, $19.67 \pm 0.58 \mathrm{ZOI}$ against $P$ seudomonas aeruginosa and $16.67 \pm 0.58 \mathrm{ZOI}$ against Enterobacter aerogenes. Isolate (B) 3 showed $21.67 \pm 0.58 \mathrm{ZOI}$ against Bacillus subtilis, $17.33 \pm 0.58 \mathrm{ZOI}$ against Staphylococcus aureus, 20.00 \pm 1 ZOI against Escherichia coli, $20.00 \pm 1$ ZOI against Klebsiella aerogenes, $18.67 \pm 0.58 \mathrm{ZOI}$ against Pseudomonas aeruginosa and $15.33 \pm 0.58 \mathrm{ZOI}$ against Enterobacter aerogenes. Isolate (B) 4 showed $21.00 \pm 1 \mathrm{ZOI}$ against Bacillus subtilis, $21.67 \pm 0.58$ ZOI against Staphylococcus aureus, $20.00 \pm 1$ ZOI against Escherichia coli, $19.33 \pm 0.58 \mathrm{ZOI}$ against Klebsiella aerogenes, $17.00 \pm 1$ ZOI against Pseudomonas aeruginosa and $18.33 \pm$ $0.58 \mathrm{ZOI}$ against Enterobacter aerogenes. Isolate (B)5 $18.67 \pm$ 0.58 ZOI against Bacillus subtilis, $19.33 \pm 0.58$ ZOI against Staphylococcus aureus, $21.00 \pm 1 \mathrm{ZOI}$ against Proteus vulgaris, $22.00 \pm 1 \mathrm{ZOI}$ against Escherichia coli, $20.67 \pm 0.58 \mathrm{ZOI}$ against Klebsiella aerogenes and $19.33 \pm 0.58 \mathrm{ZOI}$ against Pseudomonas aeruginosa.

It was found that actinomycetes isolates produced from soil surrounding medicinal plant area total 36 isolates obtained amongst them $26(72.22 \%)$ isolates had antimicrobial activity against test pathogens and $10(27.78 \%)$ isolates not have any activity. Thirty two actinomycetes isolates produced from soil not nearby medicinal plant area amongst them 17 (53.12\%) showed antimicrobial activity against test pathogens and 15 (46.88 \%) not showed any activity. Some study shown that Rosa indica plant soil area is rich source of actinomycetes isolates, which have potent antimicrobial activity. In our study also 3 isolates out of 10 most potent isolates were from soil nearby Rosa indica $[3,6,27]$.

\section{Conclusion}

This research concluded that more number of actinomycetes isolates produced from soil surrounding medicinal plant area than soil not nearby medicinal plants of Junagadh area of Gujarat state. Actinomycetes isolates shown greater than $20 \mathrm{~mm}$ ZOI from soil surrounding medicinal plant as compare isolates produced from soil not nearby medicinal plant. Only $28 \%$ of actinomycetes isolates produced from soil surrounding medicinal plant area had not shown any activity against pathogens while isolates produced from soil not nearby medicinal plant shown $47 \%$ of isolates had not any activity.

\section{CONFLICT OF INTEREST}

The authors declare that there is no conflict of interests regarding the publication of this article.

\section{REFERENCES}

1. R. Jacoby, M. Peukert, A. Succurro, A. Koprivova and S. Kopriva, Front Plant Sci., 8, 1617 (2017). https://doi.org/10.3389/fpls.2017.01617.

2. T. Cavalier-Smith, M. Brasier and T.M. Embley, Philos. Trans. R. Soc. Lond. B Biol. Sci., 361, 845 (2006); https://doi.org/10.1098/rstb.2006.1847.

3. P.C. Baveye, W. Otten, A. Kravchenko, M. Balseiro-Romero, É. Beckers, M. Chalhoub, C. Darnault, T. Eickhorst, P. Garnier, S. Hapca, S. Kiranyaz, O. Monga, C.W. Mueller, N. Nunan, V. Pot, S. Schlüter, H. Schmidt and H.-J. Vogel, Front. Microbiol., 9, 1929 (2018); https://doi.org/10.3389/fmicb.2018.01929.

4. K.F. Chater, F1000Res., 5, 2795 (2016); https://doi.org/10.12688/f1000research.9534.1.

5. R.E. de Lima Procópio, I.R. da Silva, M.K. Martins, J.L. de Azevedo and J.M. de Araújo, Braz. J. Infect. Dis., 16, 466 (2012); https://doi.org/10.1016/j.bjid.2012.08.014.

6. R.F. Seipke, M. Kaltenpoth and M.I. Hutchings, FEMS Microbiol. Rev., 36, 862 (2012); https://doi.org/10.1111/j.1574-6976.2011.00313.x.

7. G. Chandra and K.F. Chater, FEMS Microbiol. Rev., 38, 345 (2014); https://doi.org/10.1111/1574-6976.12047.

8. L. Xi, J. Ruan and Y. Huang, Int. J. Mol. Sci., 13, 5917 (2012); https://doi.org/10.3390/ijms13055917.

9. B.K. Nanjwade, S. Chandrasekhar, P.S. Goudanavar, M. Shamarez and F.V. Manvi, Trop. J. Pharm. Res., 9, 373 (2010); http://dx.doi.org/10.4314/tjpr.v9i3.3.

10. G. Gebreyohannes, F. Moges, S. Sahile and N. Raja, Asian Pac. J. Trop. Biomed., 3, 426 (2013); https://doi.org/10.1016/S2221-1691(13)60092-1.

11. S.T. Williams and T. Cross, ed.: C. Booth, Actinomycetes, In: Methods in Microbiology, Academic Press: London (1971).

12. S.S. Kesavan and R. Hemalatha, Asian J. Pharm. Clin. Res., 8, 110 (2015).

13. M. Balouiri, M. Sadiki and S.K. Ibnsouda, J. Pharm. Anal., 6, 71 (2016); https://doi.org/10.1016/j.jpha.2015.11.005.

14. C. Valgas, S.M. Souza, E.F.A. Smânia and A. Smania Jr, Braz. J. Microbiol., 38, 369 (2007); https://doi.org/10.1590/S1517-83822007000200034.

15. C. Manjula, P. Rajguru and M. Muthuselvam, Adv. Biol. Res. (Faisalabad), 3, 84 (2009).

16. T.D. Gurung, C. Sherpa, V.P. Agrawal and B. Lekhak, Nepal J. Sci. Technol., 10, 173 (1970); https://doi.org/10.3126/njst.v10i0.2957.

17. E.M.A. Da Silva and J.S. Santos, Afr. J. Microbiol. Res., 4, 1654 (2010).

18. E. Busti, P. Monciardini, L. Cavaletti, R. Bamonte, A. Lazzarini, M. Sosio and S. Donadio, Microbiology, 152, 675 (2006); https://doi.org/10.1099/mic.0.28335-0.

19. X.C. Wu, W.F. Chen, C.D. Qian, O. Li, P. Li and Y.P. Wen, J. Microbiol. (Korea), 45, 499 (2007).

20. L. Deepika and K. Kannabiran, J. Microb. Biochem. Technol., 2, 1 (2010); https://doi.org/10.4172/1948-5948.1000015.

21. V. Murugamani, T. Bharathi and K.N. Jayaveera, Internet J. Microbiol., 5, 1 (2008).

22. D.T. Lakshrnipathy and K. Kannabiran, Am. J. Infect. Dis., 5, 207 (2009).

23. K. Rajendran, N. Dhamodharan and C. Dhivya, Asian J. Pharm. Clin. Res., 10, 92 (2017); https://doi.org/10.22159/ajpcr.2017.v10i3.14472.

24. R. Rajesh Kan and S.G. Prakash Vi, Asian J. Biotechnol., 3, 237 (2011); https://doi.org/10.3923/ajbkr.2011.237.245.

25. D. Thakur, A. Yadav, B.K. Gogoi and T.C. Bora, J. Med. Mycol., 17, 242 (2007); https://doi.org/10.1016/j.mycmed.2007.08.001

26. S. Peela and S. Porana, Int. J. Curr. Pharm. Res., 9, 40 (2016); https://doi.org/10.22159/ijcpr.2017v9i1.16603.

27. M.G. Saleh, S.M.S. Jamal, A.M.H. Amr, A.K. Saleh, A.T. Dina and M.A. Mohamed, J. Food Agric. Environ., 12, 1072 (2014). 